
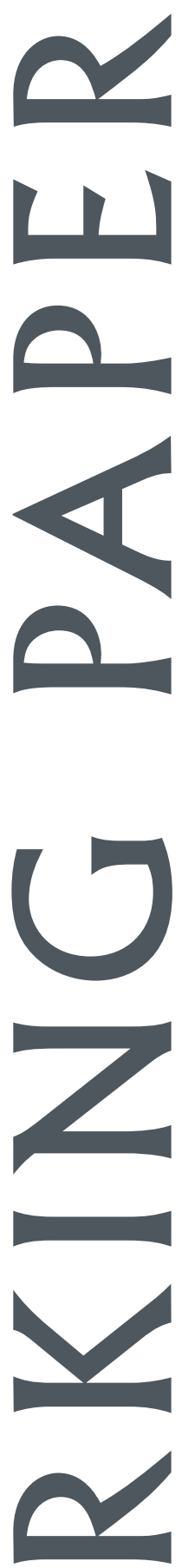

EAST-WEST CENTER 
The U.S. Congress established the East-West Center in 1960 to foster mutual understanding and cooperation among the governments and peoples of the Asia Pacific region including the United States. Funding for the Center comes from the U.S. government with additional support provided by private agencies, individuals, corporations, and Asian and Pacific governments.

East-West Center Working Papers are circulated for comment and to inform interested colleagues about work in progress at the Center.

For more information about the Center or to order publications, contact:

Publication Sales Office

East-West Center

1601 East-West Road

Honolulu, Hawaii 96848-1601

Telephone: 808-944-7145

Facsimile: 808-944-7376

Email: ewcbooks@EastWestCenter.org

Website: www.EastWestCenter.org 


\title{
Open Trade With the U.S. Without Compromising Canada's Ability to Comply With It's Kyoto Target
}

\author{
ZhongXiang Zhang
}

ZhongXiang Zhang is a Fellow in the Research Program at the East-West Center. He also is a part-time professor of economics at both the Chinese Academy of Social Sciences and Peking University, Beijing. He is the author of The Economics of Energy Policy in China: Implications for Global Climate Change (Edward Elgar, 1998) and co-author of International Rules for Greenhouse Gas Emissions Trading (United Nations, 1999). Currently, he is serving on the editorial boards of seven international journals and one Chinese journal. He has also served as an expert/consultant to many national and international organizations. He has presented research findings in more than 25 countries over the past six years, and has been included in Marquis Who's Who in Science and Engineering and Who's Who in the World.

East-West Center Working Papers: Environmental Change, Vulnerability, and Governance Series is an unreviewed and unedited prepublication series reporting on research in progress. The views expressed are those of the authors and not necessarily those of the Center. Please direct orders and requests to the East-West Center's Publication Sales Office. The price for Working Papers is $\$ 3.00$ each plus postage. To destinations within the U.S. and its territories: for surface mail, add $\$ 3.00$ for the first paper plus $\$ 0.75$ for each additional title or copy sent in the same shipment; for airmail add $\$ 4.00$ for the first paper plus $\$ 1.25$ for each additional title or copy in the same shipment. To destinations elsewhere: for surface mail, add $\$ 6.00$ for the first paper plus $\$ 1.50$ for each additional title or copy sent in the same shipment; for airmail, add $\$ 7.50$ for the first paper plus $\$ 3.50$ for each additional title or copy in the same shipment. 


\title{
Open trade with the U.S.
}

\section{without compromising Canada's ability to comply with its Kyoto target}

\author{
ZhongXiang Zhang* \\ Research Program \\ East-West Center \\ 1601 East-West Road \\ Honolulu, HI 96848-1601, USA \\ Tel: +1-808-944 7265 \\ Fax: +1-808-944 7298 \\ Email: ZhangZ@EastWestCenter.org
}

* Fellow, Research Program, East-West Center, Honolulu, USA; Part-time Professor of Economics, at both Centre for Environment and Development, Chinese Academy of Social Sciences, Beijing, China and China Centre for Regional Economic Research, Peking University, Beijing, China. 


\begin{abstract}
There are no other two countries in the world that trade as much between themselves as do Canada and the U.S.. It should thus come as no surprise that the U.S. deviation from international obligations makes Canadian industries' competitiveness (trade) concerns become even more rigorous. Against this background, this paper aims to address competitiveness concerns brought about by the different level playing field where Canadian industries face mandatory emissions constraints but U.S. industry' emissions are uncapped. To that end, the paper has addressed: 1) ways to deal with increased emissions in Canada as a result of increasing energy exports to the U.S.; 2) treatment of Canadian subsidiaries of U.S. multinationals in initially allocating Canada's assigned amount; 3) transferring Kyoto permits to non-Annex B Parties and transferring credits generated by non-Kyoto Parties to Kyoto Parties; 4) whether does the U.S. bear any economic costs even when it faces no mandatory emissions targets during the first commitment period and why does Canada like to bear additional costs, if any, relative to the U.S. and the EU.? and 5) what other measures might Canada take to further mitigate its trade concerns, in addition to taking advantage of the opportunities offered by the Kyoto flexibility mechanisms? If Canada and other like-minded countries invoke trade measures (to meet their Kyoto targets) against another WTO member but non-Kyoto Party like the U.S, would these measures be uphold if challenged by the U.S. under WTO? In so doing, attention is paid to the trade effects of the proposed measures to ensure their close consistency with the WTO rules, thus maximizing the WTO's contributions to sustainable development. It should be pointed out that although this study focuses on the U.S. and Canada, the results are of highly policy relevance to Japan and the EU as well. The latter also have to address the similar issues facing with Canada, although to less extent.
\end{abstract}

Keywords: clean energy exports; emissions trading; competitiveness concerns; border tax adjustments; WTO; Kyoto Protocol

JEL: F18; Q28; Q48; Q43 


\section{Introduction}

The U.S. and Canada are two important partners of the North American Free Trade Agreement (NAFTA). Canada, together with most industrialized countries, has ratified the Kyoto Protocol and begins implementing domestic policy measures aimed at meeting its legally binding Kyoto emissions target. In the mean time, the U.S. has made clear that it will pursue a separate climate strategy as outlined by the Bush Climate Change Initiative, and thus that it will at least initially not be part of the international regime. Given that no other two countries in the world trade as much between themselves as do Canada and the U.S., Canadian industries have much greater competitiveness (trade) concerns brought about by the different level playing field where Canadian industries face mandatory emissions constraints but U.S. industry' emissions are uncapped than Japanese and European counterparts. All this puts Canada in a very difficult position in meeting its Kyoto target, in comparison with Japan and the European Union (EU). Thus, focus on the U.S. and Canada is of much higher policy relevance than, say, focus on the U.S. and Japan/the EU. Against this background, this paper aims to address the following six major policy issues.

First, how to deal with increased emissions in Canada as a result of increasing energy exports to the U.S.? Canadian energy exports to the U.S. are bound to increase under the new U.S. energy security policy. Consequently, this will greatly increase emissions in Canada, and further increase Canada's difficulty in meeting its Kyoto target. Is Canada's proposal for providing credits for cleaner or less greenhouse gas-emitting energy exports a practical and politically realistic approach to addressing this issue? 
Second, given that Canadian subsidiaries of U.S. multinationals compete with all local entities in Canada for permits. The question is whether the former are allowed to get access to Canadian assigned amount units in the initial allocation of permits. If not, discrimination against companies on the basis of ownership would transgress World Trade Organization (WTO) rules.

Third, if the U.S. adopts domestic mandatory emissions limits and decides to recognize Kyoto permits for purpose of compliance with its domestic requirements, should the Kyoto Parties like Canada are allowed to transfer their permits to non-Kyoto Parties like the U.S.? This is very important not only because it virtually makes U.S. based firms bear mitigation costs but also because it is essential for intra-firm emissions trading within a multinational corporation, as experienced by British Petroleum and Shell. This also increases overall demand for Kyoto permits and pushes up the price of permits, thus increasing incentives to invest in clean development projects in developing countries.

Fourth, whether the Kyoto Parties like Canada recognize those credits generated by non-Kyoto Parties like the U.S. and allow them to enter the Kyoto market? If nonKyoto permits are allowed to enter the Kyoto market, there is a great danger of raising the overall allowed emissions level under the Kyoto Protocol, thus undermining the environmental integrity of the Kyoto Protocol. Moreover, although nothing in the Kyoto Protocol prevents Kyoto Parties from selling permits to buyers in non-Kyoto Parties like the U.S., recognising credits from emissions reduction projects in non-Kyoto Parties like the U.S would require an amendment to the Protocol. To date, some Japanese companies have invested in sinks projects in Australia. Following the above interpretation, if 
Australia remains a non-Kyoto Party, the credits generated by these projects will not be eligible to be used to offset emissions in Japan even if the carbon accounting is line with the Kyoto Protocol methodology. The question boils down to whether there are ways to ensure no net inflow of non-Kyoto credits into the Kyoto regime without restricting flexibility of trading between Kyoto and non-Kyoto Parties.

Fifth, Canada agreed at Kyoto to a target of 6 percent reduction in greenhouse gas emissions on the basis of U.S. parity effort at 7 percent reduction, would the U.S. deviation from international obligations lead to no economic costs at all to the U.S.? Given that the policy context has changed substantially from the early days of the climate change negotiations when nations were considering full Annex B implementation of the original Kyoto targets, would additional costs bored by Canada appear that high relative to the U.S. and the EU after factoring in the sinks credits allowed in the Marrakech Accords and taking advantage of the opportunities offered by the Kyoto flexibility mechanisms?

Sixth, provided that non-Kyoto Parties like the U.S. are seen as exploiting their lack of emissions constraints for competitive advantage, should the Kyoto Parties like Canada are allowed to give some degree of preferential treatment of their domestic companies and those of other Kyoto Parties over those of non-Kyoto Parties? If Canada, EU and other like-minded countries invoke trade measures (to meet their Kyoto targets) against another WTO member but non-Kyoto Party like the U.S, would these measures be uphold if challenged by the U.S. under WTO?

Clearly, if these issues are not addressed appropriately, open trade with the U.S. could compromise Canada's ability to comply with its Kyoto target. The paper aims to 
address these very important issues and formulate policy measures that Canada can adopt to meet its Kyoto obligations. In so doing, attention is paid to the trade effects of the proposed measures to ensure their close consistency with the WTO rules, thus maximizing the WTO's contributions to sustainable development.

It should be pointed out that although this study focuses on the U.S. and Canada, the results are of highly policy relevance to Japan and the EU as well. The latter also have to address the similar issues facing with Canada, although to less extent. In the international arena, the results are of particular interest to those who seek the solutions to linkages between U.S. and international emissions trading regimes.

\section{Canada's energy exports to the U.S.}

Canadian energy exports to the U.S. are bound to increase under the new U.S. energy security policy. Consequently, this will greatly increase emissions in Canada, and further increase Canada's difficulty in meeting its Kyoto target. The question is how to deal with increased emissions in Canada as a result of increasing energy exports to the U.S..

One way is to let that the price of energy exported reflects (or counts) the environmental and social externalities associated with its production, thus internalising the corresponding environmental (abatement) costs. For example, in Norway, almost 100 percent of electricity is produced from large hydropower. In dry seasons, Norway needs to import electricity from coal-fired plants in Denmark to meet its electricity demand. The more electricity Denmark exports to Norway, the more difficult Denmark becomes in meeting its Kyoto emissions target. To mitigate its burden, Denmark factors in the cost 
of carbon abatement in electricity pricing. ${ }^{1}$ Internalising the abatement cost this way is justified from the social and environmental perspectives, and will be compatible with trade rules as long as such a practice does not treat domestic and foreign electricity consumers unequally. Similarly, Canada could incorporate the abatement cost associated with the production of energy exported in energy pricing.

Another way is to increase the amount of cleaner or less greenhouse gas-emitting energy exports to the U.S.. Currently, Canada produces and exports substantial amount of natural gas and hydropower to the U.S.. Over 50 percent of the natural gas produced in Canada is exported to the U.S. Canada exports about 7 percent of its total generated electricity to the U.S, with 93 percent of the export from hydropower (UNFCCC, 2002a). The growth in the export of natural gas from Canada is projected to nearly quadruple over the period 1990-2010 (UNFCCC, 2000b). Canada has argued that these clean energy exports reduce U.S. and global emissions and thus is entitled to receive credits for emissions reductions resulting from these clean energy exports (UNFCCC, 2002a). Is Canada's proposal for providing credits for cleaner or less greenhouse gas-emitting energy exports a practical and politically realistic approach to addressing this issue?

Canada's proposal for permitting it to receive assigned amount units equivalent to the global environmental benefit from its exports of cleaner energy received support from a few countries. Most countries, including the Group of 77 and China, the EU, the U.S., Norway and Switzerland opposed the proposal. Many countries questioned its potential precedent-setting effects that lead to a potentially overwhelming amount of requests for credits of cleaner energy from other countries rather just than Canada and legal basis of

\footnotetext{
${ }^{1}$ The price of permits gradually emerging from the international permits markets and the price of certified emission reductions (CERs) from clean development projects provide a reference for the cost of abatement that will be added to the current electricity price.
} 
whether the proposal would fit into the framework of the Kyoto Protocol (UNFCCC, 2000b; IISD, 2002).

Canada's proposal was also viewed by many as an attempt to reopen the deal just struck in Marrakesh, November 2001 (IISD, 2002). In the Canadian proposal, Canada estimates that its exports of cleaner energy to the U.S. lead to the reduction of 70 million tons of $\mathrm{CO}_{2}$ equivalent in the U.S. in comparison with case of no such exports. Although all the countries benefit from such a reduction, the U.S. is perceived the main beneficiary because the exports to the U.S. make the U.S. easier to meet its emissions target. Thus, it would be logical to ask the U.S. to provide the credits asked by Canada. But now, the U.S. is out of the Kyoto Protocol, implying that even if U.S. were willing to provide credits, U.S. credits would have no recognition within the Kyoto regime (see Section 4 for further discussion on the issue of transferring credits generated by non-Kyoto Parties like U.S. to Kyoto Parties like Canada). So, providing such credits to Canada to avoid its inventory imbalance would need to re-open the deal just struck in Marrakesh on the assigned amount under the Kyoto Protocol. This will distract from the implementation task and focus, as negotiators would focus on the already-agreed commitments for the first commitment period again.

Putting these political and legal uncertainties aside, it is fair to say that crediting exports of cleaner or less greenhouse gas-emitting energy is a complex undertaking. It could open the paradox's box of containing many issues unlikely to be resolved to every party satisfaction. First, on methodology, it is very complex to establish credible counterfactual baselines on which avoided global emissions are estimated as a result of Canada's cleaner energy exports. Second, if credits are provided for exports of cleaner 
energy, it seems reasonable to credit the exports of energy-efficient goods other than energy that also lead to lower global greenhouse gas emissions. This raises two questions: a) how might energy-efficient goods be properly defined? b) there would be formidable technical difficulties, if not entirely impossible, in identifying the appropriate energy/carbon contents embodied in traded energy-efficient products. Third, if credits are provided for exports of cleaner energy, countries suffering from the damages caused from the exports of unclean energy would demand for compensation. This issue then becomes linked to the so-called policies and measures and the resulting adverse effects in the international climate negotiations, the thorny issues on which international climate negotiators are unable to reach any substantial conclusions.

\section{Treatment of Canadian subsidiaries of U.S. multinationals in the initial allocation of permits}

Canadian subsidiaries of U.S. multinationals are legal entities established under Canadian constitutions. Like all existing domestic entities in Canada and Canadian subsidiaries of other multinationals, these Canadian subsidiaries of U.S. multinationals also need emissions permits to operate in Canada. Thus, they compete with all local entities and other foreign-owned entities in Canada for emissions permits in the initial allocation of permits for two reasons.

First, if the U.S. adopts mandatory domestic emissions limits, the U.S. multinationals could potentially make use of low cost emissions reductions options available from their operations in Kyoto Annex B parties like Canada in order to meet U.S. emissions targets. This will increase overall demand for Kyoto permits and thus 
push up the price of Kyoto permits. However, given U.S. rejection of the Kyoto Protocol, even if the U.S. adopts mandatory domestic emissions limits, they will be very lenient. Thus, it appears unlikely that the price of permits in Canada will be lower than the domestic price of permits in the U.S.. In particular, given the availability of CERs at even low cost, it is very unlikely that the U.S. multinationals will resort to their Canadian subsidiaries for low cost abatement options.

Second and most importantly, located in the territory of Canada, these subsidiaries are obligated to follow the same rules as any other Canadian entities and cannot emit more than the levels allowed by the Canadian government. In the mean time, they are entitled to get access to Canadian assigned amount units in the initial allocation of permits. How they are treated in the initial allocation of permits raises great trade concerns.

Two methods are commonly used to initially allocate permits. Individual emissions sources can benefit greatly depending on which allocation method is chosen. One often-discussed allocation method is a form of grandfathering, whereby the permits are given out freely to existing regulated entities in proportion to their historical emissions or fossil fuel sales. For example, in the U.S. $\mathrm{SO}_{2}$ allowance trading program mandated in Title IV of the Clean Air Act Amendments of 1990, the basic allocation formula has been free distribution of available allowances among generating units within the regulated plants in proportion to their average fossil fuel consumption during the baseline period 1985-1987 multiplied by the respectively specified amount of $\mathrm{SO}_{2}$ emissions per unit of energy for Phase I and for Phase II (Ellerman et al., 1997). Grandfathering would have the advantage of minimizing the disruption of current production of the regulated entities (Zhang, 1997). 
With grandfathering, emissions sources could also save considerable expenditures, because they only have to pay for additional permits as needed. Therefore, it increases the political acceptability of an emissions trading scheme (Baumol and Oates, 1988). However, like stringent command-and-control standards for new sources, grandfathering gives rise to entry barriers for new sources to enter the market, because they must buy their emissions permits while existing sources obtain theirs for free (Stavins, 1998; Tietenberg et al., 1999).

The alternative to grandfathering is that the government would require prospective permits buyers to bid for permits in an auction. The adopted annual auction of $\mathrm{SO}_{2}$ allowances in the U.S. $\mathrm{SO}_{2}$ allowance trading program, which represents less than 2 percent of the total allowance allocation and thus is a trivial part of the overall program (Ellerman et al., 1997), is structured as a sealed-bid auction with pay-your-bid-pricing. Potential buyers are required to simultaneously send bids in sealed orders, stating the number of the permits they are willing to buy at a stated maximum price. The auctioneer then supplies permits beginning with the highest bidder until the excess supply is zero. Unlike in a stock market where there is one single price at any time, this form of auction creates many different settlement prices. Alternatively, a sealed-bid auction could be designed in such a manner that all winners pay the price of the marginal buyer, that is, the clearing price for each permit. Unlike in a sealed-bid auction with pay-your-bid-pricing where the bidders attempt to guess where the clearing price is likely to be, predicting the clearing price is less important in an auction with uniform pricing, since every winner pays the same price no matter how high it bids. This form of auction also encourages participation by small bidders, since it is strategically simple. ${ }^{2}$

\footnotetext{
${ }^{2}$ The alternative to a sealed-bid auction is an ascending-bid auction. Cramton and Kerr (2002) compare different auction forms and conclude that, from an efficiency perspective, probably the best auction form is
} 
Auctioning permits is aimed to serve two purposes. One is to ensure that permits are available for small and new sources. The second purpose is to deliver signals on permit prices. Many analysts often argue that auctioning is superior to grandfathering in the initial allocation of permits on the following grounds. First, auctioning generates revenues that could be used to reduce pre-existing distortionary taxes, thus generating overall efficiency gains. Parry et al. (1999), for example, show that the costs of reducing U.S. carbon emissions by 10 percent in a second-best setting with pre-existing labour taxes are five times more costly under a grandfathered carbon permits case than under an auctioned case. This is because the policy where the permits are auctioned raises revenues for the government that can be used to reduce pre-existing distortionary taxes. By contrast, in the former case, no revenue-recycling effect occurs, since no revenues are raised for the government. However, the policy produces the same tax-interaction effect as under the latter case, which tends to reduce employment and investment and thus exacerbates the distortionary effects of pre-existing taxes. Because the policy where the permits are given out freely under a grandfathered case does not produce the revenue-recycling effect to counteract the tax-interaction effect, it has a higher economic cost than a policy where the permits are auctioned under an auctioned case. Second, it provides a stronger incentive for technical innovation (Milliman and Prince, 1989). Third, auctioning eliminates the need to establish historical baselines for the regulated entities and helps to ease political contention in the allocation of scarcity rents, which occurs if the permits are grandfathered (Hausker, 1992; ELI, 1997). Fourth, revenues raised from auctioning could be used to directly compensate those affected workers and consumers, and thus the equity goal could be better

a standard ascending-clock auction, in which price is gradually raised until there is no excess demand. However, given the complexity associated with ascending-bid auctions, the desirability of adopting an ascending-clock auction needs to be weighted against the feasibility of doing so. 
achieved under auctioning than under grandfathering. Despite all these advantages of auctioning, however, all the existing trading programs have initially allocated the permits through grandfathering, partly because it provides greater political control over the distributional effects of regulation (Stavins, 1998).

The initial allocation process itself represents the establishment and distribution of private property rights over emissions, and itself lies outside the mandate of the WTO (Vaughan, 1997). Given the great concern about international competitiveness, however, the allocation of permits does have the potential to bring parties into conflict with the WTO provisions. Some fear, for example, that governments could allocate the permits in such a manner to favour domestic firms against foreign rivals. For example, a government of country X - Canada in our case - might allocate a generous amount of permits to a domestic firm, while similar foreign firms also operating in the same industry of country $\mathrm{X}$ Canadian subsidiaries of U.S. multinationals in our case - might get the tight emissions budgets. A government like Canada grandfathers permits to its domestic firms, while similar Canadian subsidiaries of U.S. multinationals have to buy permits. These differential treatments on the basis of ownership in the initial allocation of permits will violate the WTO principle of non-discrimination. All this clearly indicates that the manner in which countries allocate their assigned amount should be compatible with these WTO principles and should not constitute a means of arbitrary or unjustifiable discrimination or a disguised restriction on international trade (Zhang, 1998, 1999).

However, it should be pointed out that although discrimination against existing companies on the basis of ownership will transgress the WTO rules, nothing under the WTO rules prohibits discriminating against new emissions sources (whether domestic 
entities or Canadian subsidiaries of U.S. multinationals) on the basis of national

treatment. In fact, environmental regulations and laws in many countries including the U.S. have discriminated against new sources for decades, by imposing more stringent environmental standards on them than those on existing sources, without ever triggering a WTO challenge.

\section{Trading between Annex B Parties and non-Annex B Parties}

Trading between Annex B Parties like Canada and non-Annex B Parties like the U.S. involves in two ways of transfers: 1) transferring Kyoto permits to non-Annex B Parties and 2) transferring credits generated by non-Kyoto Parties to Kyoto Parties. The question is whether these two ways of transfers have been authorized under the Kyoto Protocol. If not, whether is there a need to authorize such transfers via an amendment to the Protocol?

With the U.S. withdrawal from the Protocol, it appears most likely that the U.S. will pursue a separate climate change strategy involving only voluntary measures. Whether and when the U.S. will mandate any domestic emissions reductions and adopt a domestic cap-and-trade system remain unknown at the time being. Assuming that the U.S. adopts domestic mandatory emissions limits and decides to recognize Kyoto permits for purpose of compliance with the U.S. domestic requirements, ${ }^{3}$ the Kyoto Parties like Canada are allowed to transfer their permits to non-Kyoto Parties like the U.S. because nothing in the Kyoto Protocol prevents Kyoto Parties from selling their permits to buyers in non-Kyoto Parties like the U.S. This is very important not only because it virtually

\footnotetext{
${ }^{3}$ Even if those Kyoto permits acquired by a non-Annex B Party entity are not recognised under its domestic climate regime at the time being, the entity could still be interested in acquiring Kyoto permits either on the expectation of being required to cut its emissions in the second comment period when the nonAnnex B Party re-enters the Protocol or strictly for speculative profits on the secondary markets.
} 
makes U.S. based firms bear mitigation costs but also because it is essential for intra-firm emissions trading within a multinational corporation. As experienced by British Petroleum and Shell, all things being equal, corporations would rather reduce emissions internally than purchase emissions reductions generated outside their own operations (Fauteux, 2002). This also increases overall demand for Kyoto permits and pushes up the price of permits, thus increasing incentives to invest in clean development projects in developing countries.

Even if the Kyoto Parties are allowed to transfer their permits to non-Kyoto Parties, the next question is how to address the accounting of these transferred Kyoto permits in their national registries. On the one hand, because these transferred permits are part of the transferring Party's assigned amount, in order not to undermine the environmental integrity of the Protocol, those Kyoto permits transferred to non-Annex B Parties should be cancelled in the transferring Annex B Party' registry. On the other hand, it is desirable to allow those transferred Kyoto permits to re-enter the Kyoto market at some later date in the commitment period to promote the overall economic efficiency of the market. Those permits transferred back to the transferring Party should be added to the Party' registry. Clearly, the net transfers matter here. But the amount of those permits transferred back is unknown until the end of the commitment period. To struck a balance between the environmental effectiveness and the economic efficiency, it has been suggested that only the net transferred permits should be cancelled in the Annex B Party' registry and that such a cancellation could be delayed until the end of the commitment period (Fauteux, 2002). These cancelled permits would be put into the transferring Annex 
B Party' cancellation account and thus are taken out of the circulation in the Kyoto system.

The situation is quite different with respect to transferring credits generated by non-Kyoto Parties to Kyoto Parties. Some analysts (e.g., Bodansky, 2002) have argued that recognising credits from emissions reduction projects in non-Kyoto Parties like the U.S. would require an amendment to the Protocol. The Canadian government has made it clear that it has no interest at all in supporting an amendment to the Protocol for this purpose (Fauteux, 2002). It is conceivable that other major negotiating Parties also have no interest in amending the Protocol to recognize those credits generated by non-Kyoto Parties like the U.S. and allow them to enter the Kyoto market, although for reasons very different from each other as explained below.

Many economic studies (e.g., Löschel and Zhang, 2002; Manne and Richels, 2003) show that the U.S. withdrawal from the Protocol already leaves plenty of excess hot air of zero costs. Adding credits generated by non-Kyoto Parties like the U.S. to the weak Kyoto market will further push down the international price of permits. This will substantially reduce incentives to invest in clean development projects that imply reduced financial flows channelled to developing countries through clean development mechanism (CDM). Thus, developing countries will oppose such an amending so that they can benefit from the corresponding high price of permits. After all, their CERs from CDM projects, although less costly than the equivalent amount of abatement undertaken within Annex B purchasing countries, are not made available at zero costs. Countries with economy in transition also oppose it because the inclusion of credits generated by non-Kyoto Parties on the supply side will depress the market price received for their sold 
permits and thus lower their revenues from selling surplus permits. For the remaining Kyoto-constrained Annex B countries, the inclusion of credits generated by non-Kyoto Parties will reduce their costs of compliance. However, some Organisation for Economic Co-operation and Development (OECD) countries, particularly the EU more concerned about the environmental effectiveness of the Kyoto Protocol, don't like to see the permit price falling because it will lead to very little domestic abatement actions. Thus, they would oppose amending the Protocol to include credits generated by non-Kyoto Parties. They would also oppose amending the Protocol for this purpose, because allowing credits generated by non-Kyoto Parties like the U.S. to enter the Kyoto market is considered as actually rewarding the US for its slack effort of meeting its carbon intensity target.

This unlikelihood of an amendment will have very important implications. To date, some Japanese companies have invested in sinks projects in Australia. That means that if Australia remains a non-Kyoto Party, the credits generated by these sinks projects will not be eligible to be used to offset emissions in Japan even if the carbon accounting is line with the Kyoto Protocol methodology.

Nevertheless it is possible to trade between Kyoto permits and non-Kyoto credits via a clearinghouse system, whereby U.S. firms that wish to export U.S. credits to Kyoto Parties could exchange them for Kyoto permits and then sell the Kyoto permits back into the Kyoto market. Two technical questions need to be resolved. The first question is the exchange rate at which one ton of non-Kyoto credits is equivalent to one ton of Kyoto permits. Provided that the exchange rate can be worked out, the next question boils down to whether there are ways to ensure no net inflow of non-Kyoto credits into the Kyoto regime. In this regard, a gateway may be needed to ensure that the allowed emissions 
levels for each Kyoto Party remain unchanged even without restricting flexibility of trading between Kyoto and non-Kyoto Parties. ${ }^{4}$

\section{The roles of Kyoto flexibility mechanism and sinks}

At Kyoto, Canada agreed to a target of 6 percent reduction in greenhouse gas emissions on the basis of U.S. parity effort at 7 percent reduction. At first glance, the U.S. withdrawal from the Protocol puts Canada at difficult position. On the other hand, the policy context has changed substantially from the early days of the climate change negotiations when nations were considering full Annex B implementation of the original Kyoto targets.

The sixth Conference of the Parties (COP6) to the United Nations Framework Convention on Climate Change (UNFCCC) held in the Hague, November 2000, aimed to finalize the procedures and institutions needed to make the Kyoto Protocol fully operational. During the negotiations leading up to the conference, the long and contentious debates between the EU on the one hand and the U.S. and other members of the Umbrella Group ${ }^{5}$ on the other hand had centred on the two issues. The first contentious issue is to what extent Annex 1 countries could count their carbon absorbing forests and agricultural lands (the so-called sinks) against their emissions targets. The U.S. was keen on the broadest and most generous definitions of sinks absorbing

\footnotetext{
${ }^{4}$ Under the United Kingdom emissions trading scheme, a gateway has been established between the absolute and rate-based sectors to avoid inflating the allowed emissions levels of the absolute sectors from the rate-based sectors (DEFRA, 2001). The gateway will close whenever aggregate sales from the ratebased sectors to the absolute sectors match the sales in the other direction.

${ }^{5}$ The Umbrella Group refers to the so-called JUSSCANNZ countries (Japan, the United States, Switzerland, Canada, Australia, Norway, New Zealand). It meets daily during the international climate change negotiations to exchange information and discuss substance/strategy on issues where there is common ground.
} 
greenhouse gases in the atmosphere, while the Europeans wanted sharp curbs on the use of sinks. The clash between the U.S. and the EU over the extent of usage of the sinks to meet their emissions targets was blamed, in part, for the breakdown of the climate negotiations of the COP6. The second contentious issue is to what extent Annex 1 countries are allowed to use the flexibility mechanisms to meet their emissions targets. On the one hand, the U.S. and other Umbrella Group members have advocated unrestricted emissions trading. On the other hand, the EU put forward a proposal for quantitative ceilings on the use of flexibility mechanisms (European Union, 1999), insisting that domestic abatement actions should be a main means of meeting emissions reductions required of each Annex 1 country (in other words, at least half of the emissions reductions required have to be undertaken domestically). This supplementary requirement caused the deepest division between the EU and the Umbrella Group countries and was regarded as one of the main causes for the collapse of the COP6.

Soon after coming into office, the President Bush decided that the U.S. would withdraw from the Kyoto Protocol. Quick to accept that the U.S. would not re-enter the negotiations, the EU led a sustained diplomatic effort to keep the Kyoto Protocol alive (Legge, 2001). While the Group of 77 and China ${ }^{6}$ moderated some of their demands, the EU softened its stance on the extent of usage of sinks and flexibility mechanisms to secure the reluctant support of other Umbrella Group members for the Protocol at the resumed COP6 held in Bonn, July 2001. After tough negotiations, the political compromises were eventually reached on a number of key implementation issues of the

\footnotetext{
${ }^{6}$ As has been the case at the international climate change negotiations, the developing countries express their consensus views as the Group of 77 and China's positions. Divergent or dissenting views are then expressed separately, representing either individual countries or smaller groups, such as the Alliance of Small Island States.
} 
Kyoto Protocol. This political deal, the so-called Bonn Agreement, was translated into the detailed legal text, the so-called Marrakech Accords, at the seventh Conference of the Parties (COP7) to the UNFCCC held in Marrakech, November 2001, which was expected to be easy but turned out to be another difficult meeting. The Kyoto Protocol, as detailed in the Marrakech Accords, has been rendered fit for its ratification.

The Bonn Agreement allows for significant credits for carbon dioxide sinks. Specifically, the following activities related to land use, land use change and forestry (LULUCF) are allowed to be counted as sinks: forest management under Article 3.4, whose credits are capped to country-specific limits as given in Appendix $\mathrm{Z}$ and which total 83 million tons of carbon (MtC) per year; ${ }^{7}$ agricultural land management and revegetation activities under Article 3.4 on a net-net accounting basis without an explicit cap; afforestation and reforestation projects to be eligible under the CDM, whose contribution to a Party's assigned amount is capped at 1 percent of five times the Party's base year emissions (UNFCCC, 2001).

With the U.S. withdrawal from the Kyoto Protocol, the EU dropped its previous insistence on a cap on the use of flexibility mechanisms. The final wording at the Bonn Agreement is now that "domestic action shall thus constitute a significant element of the effort" by each Annex 1 country. This is a very important and positive development because it will allow countries and businesses to reduce their emissions wherever it is cheapest to do so. Ironically, it is a development that the U.S. had lobbied intensively for during previous rounds of international climate negotiations.

\footnotetext{
${ }^{7}$ At the COP7 to the UNFCCC, the Russian Federation demanded the renegotiation of the designated amount from forest management activities, and succeeded in increasing the amount from 17.63 megatons of carbon per year specified in Appendix Z under the Bonn Agreement to 33 megatons. This revision led to the new total of $98 \mathrm{MtC}$, provided that an initial figure of $28 \mathrm{MtC}$ for the U.S. was included.
} 
Significant sinks credits allowed in the Marrakech Accords relax the emissions targets substantially. Table 1 contains the nominal percentage reductions with respect to (wrt) 1990 emissions levels and the effective percentage reductions with respect to baseline emissions in 2010 for both the original Kyoto emissions targets and the revised targets under the Bonn Agreement and the Marrakech Accords. The latter are based on the preliminary estimates by the European Commission factoring into the amount of sinks credits as agreed in Bonn and Marrakech (Nemry, 2001). As a result of allowing countries to count the amount of sinks credits, the average reduction target for the Annex B countries as a whole is reduced to 1.9 percent, in comparison with the original reduction target of 5.2 percent. Allowing the unrestricted use of Kyoto flexibility mechanisms makes much easier for the remaining Annex B Parties to meet their relaxed targets. Consequently, if the remaining Annex B Parties (less the U.S.) were to make use of all the flexibility provided, the marginal costs of meeting their revised targets would be very low. These changes have converted the original Kyoto Protocol into a gradual-start agreement that can be achieved at prices in the single digits (Babiker et al., 2002).

There are reasons why economic studies underestimate the permits price. First, a full Annex B trading scheme would not be put in place by the end of the first commitment period so that the binding Annex B countries may be unable to reap its full benefits of bringing the compliance costs down. Second, the government's policies and the permits markets don't operate both domestically and internationally as efficiently as the models assume.

While adding sinks credits and allowing the full use of flexibility mechanisms would have lowered Canadian compliance costs substantially, a legitimate question that 
still needs to be addressed is why Canada likes to bear additional costs, if any, relative to the U.S. and the EU. This in turn raises the following two questions.

Table 1 Quantitative Implications of the Marrakech Accords

\begin{tabular}{|c|c|c|c|c|c|c|c|c|}
\hline \multirow[t]{2}{*}{ Region $^{\mathrm{a}}$} & \multicolumn{2}{|c|}{$\begin{array}{c}\text { Baseline } \\
\text { emissions } \\
(\mathrm{MtC})^{\mathrm{b}}\end{array}$} & \multicolumn{2}{|c|}{$\begin{array}{c}\text { Nominal } \\
\text { reduction } \\
(\% \text { wrt 1990 })^{\mathrm{c}}\end{array}$} & \multicolumn{2}{|c|}{$\begin{array}{c}\text { Effective } \\
\text { reduction } \\
(\% \text { wrt 2010) }\end{array}$} & \multicolumn{2}{|c|}{$\begin{array}{c}\text { Absolute } \\
\text { cutback } \\
\text { (MtC wrt 2010) }\end{array}$} \\
\hline & 1990 & 2010 & w/o sink & $\mathrm{w} / \mathrm{t} \sin \mathrm{ks}$ & w/o sinks & $\mathrm{w} / \mathrm{t}$ sinks & w/o sinks & $\mathrm{w} / \mathrm{t} \operatorname{sinks}$ \\
\hline AUN & 88 & 130 & -6.8 & -9.4 & 27.6 & 25.9 & 36 & 34 \\
\hline CAN & 126 & 165 & 6.0 & -5.2 & 28.2 & 19.7 & 47 & 32 \\
\hline EUR & 930 & 1040 & 7.8 & 6.2 & 17.5 & 16.1 & 182 & 168 \\
\hline JPN & 269 & 330 & 6.0 & 1.1 & 23.4 & 19.4 & 77 & 64 \\
\hline EEC & 279 & 209 & 7.1 & 4.9 & -24.0 & -26.9 & -50 & -56 \\
\hline FSU & 853 & 593 & 0 & -4.2 & -43.8 & -49.8 & -260 & -296 \\
\hline Total w/o US & 2545 & 2467 & 4.3 & 0.9 & 1.3 & -2.2 & 32 & -54 \\
\hline USA & 1345 & 1809 & 7.0 & 3.7 & 30.9 & 28.4 & 558 & 514 \\
\hline Total w/t US & 3890 & 4276 & 5.2 & 1.9 & 13.8 & 10.8 & 590 & 460 \\
\hline
\end{tabular}

${ }^{a}$ AUN - Australia and New Zealand; CAN - Canada; EUR - OECD Europe; JPN - Japan; EEC - Central and Eastern European countries; FSU - Former Soviet Union.

${ }^{\mathrm{b}}$ Baseline emissions in 2010 based on U.S. DOE (2001) reference case.

${ }^{c}$ Estimates based on UNFCCC and FAO data (Nemry, 2001).

${ }^{\mathrm{d}}$ Annex B total without the U.S. ratification.

${ }^{\mathrm{e}}$ Annex B total with the U.S. ratification.

Source: Löschel and Zhang (2002).

First, whether does the U.S. bear any economic costs even when it faces no mandatory emissions targets during the first commitment period? Nearly one year after pulling out of the Kyoto Protocol, the Bush administration finally announced the longawaited, domestic climate plan on 14 February 2002. The Bush plan adopted a voluntary target of reducing U.S. greenhouse gas emissions intensity by 18 percent below 2002 levels by 2012 (White House, 2002). While the target is hardly a challenge, it does require 4 percent reduction in comparison with the no new effort case which projects a 
reduction in intensity of 14 percent. Several U.S. states and many U.S. large corporations are moving ahead on their own to deal with global warming. One reason is that these U.S. multinationals know that their factories in countries that have ratified the Kyoto Protocol will have to meet local limits. Another is that many of the companies expect that despite the Bush administration's stance, it is only a matter of time before they will be required to cut their greenhouse gas emissions on their home turf. Given the long-lived nature of many energy-sector investments and great desirability of low-carbon economy, energysector investors would anticipate mandatory tighter future constraints, and thus factor this consideration into their near-term decision-making, even if no mandatory constraints are in place for them at the moment. Consequently, in adapting to tighter future constraints, energy-sector investors are making more costly investments than would be made in the absence of concerns about future carbon constraints. Thus, even in the absence of mandatory emissions targets, the U.S. emissions in 2010 would be lower than its business-as-usual baseline, as indicated in Figure 1. The U.S. also incurs GDP losses in 2010 even if it faces no mandatory constraints in that year (Manne and Richels, 2004).

The second question boils down to why Canada takes on emissions commitments in the first place. That is its depth of concern about the climate problem as many European countries do. Canada itself is particularly vulnerable to the changing climate. If climate change goes ahead unchecked, Canada will suffer enormous social, environmental and economic costs. That explains why Canada committed to emissions targets at Kyoto. Committing emissions targets implies that Canada is willing to bear some costs of reversing current trend of rising greenhouse gas emissions. However, Canada is not acting alone in combating global climate change. Many other countries 
share the same concern as Canada does. Many EU countries, although awarded with less sinks credits in the Marrakech Accords than Canada, ${ }^{8}$ even intend to do more than the minimum that would be required under the Kyoto Protocol by setting even more stringent targets domestically than agreed internationally (e.g., Sweden and the United Kingdom) or placing own restrictions on the use of flexibility afforded them (e.g., The Netherlands).

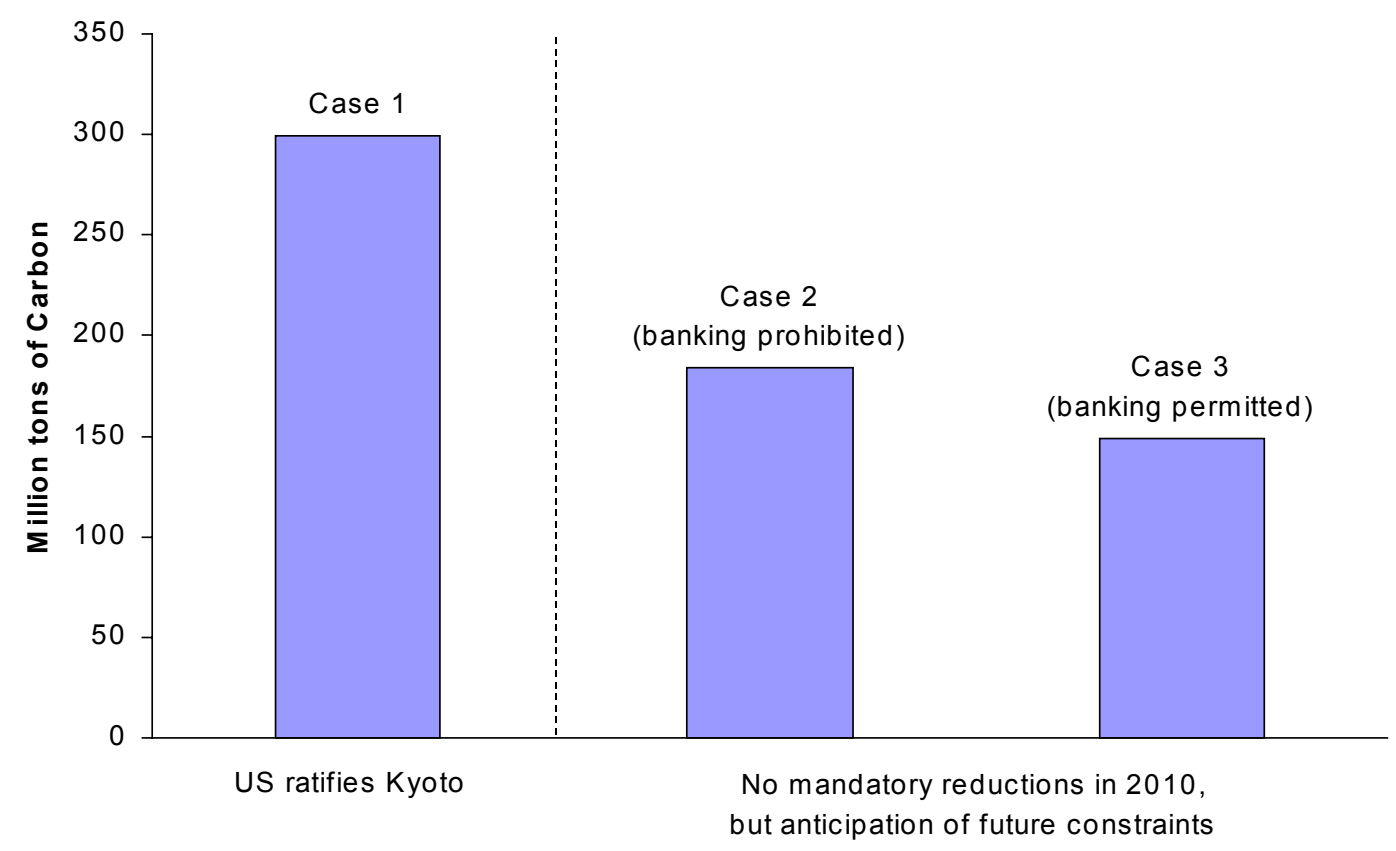

Figure 1 U.S. Domestic Emission Reductions in 2010 -- the impact of anticipation of future constraints. Source: Manne and Richels (2004).

The combined effects of anticipatory behaviour on the part of U.S. investors and great concern about the environmental effectiveness would not level the playing field

\footnotetext{
${ }^{8}$ As indicated in Table 1, factoring into the amount of sinks credits as agreed in Marrakech, Canada is even allowed to increase its emissions in 2010 by 5.2 percent relative to its 1990 level in comparison with the original reduction target of 6 percent. By contrast, the EU is required to cut its emissions in 2010 by 8 percent relative to its 1990 level under the Kyoto Protocol. Counting the amount of sinks credits only slightly relaxes its reductions targets.
} 
completely. But viewed along these angles, additional costs bored by Canada would appear not high relative to the U.S. and the EU as they appear at fist glance.

\section{Shielding vulnerable sectors and invoking trade measures against non-Kyoto Parties}

At first glance, the Kyoto Protocol is an environmental agreement aimed to reduce greenhouse gas emissions. However, meeting the Kyoto emissions targets requires a fundamental change in the way that energy is produced and the way it is used. Given that energy is a prerequisite input to fuel economic growth, therefore the Protocol is in reality an economic agreement. The U.S. is seen as exploiting their lack of emissions constraints for competitive advantage. Environmental groups, like Friends of the Earth Europe, demand the EU to impose penalties against energy intensive U.S. products in retaliation for the U.S. rejection of the Protocol. ${ }^{9}$ The EU apparently intends to view the U.S. inaction as hidden subsidies for its products, and is exploring trade measures to level the playing field.

It is conceivable that while its largest trading partner (the largest bilateral trade relationship on the globe) does not operate under the same rules, Canada is even more concerned about unfair competition than EU and Japan. The question then is how Canada mitigates competitiveness (trade) concerns brought about by the different level playing field, in addition to taking advantage of the opportunities offered by the Kyoto flexibility mechanisms discussed in the previous section.

\footnotetext{
9 "EU governments should also consider targeting specifically high energy intensive products. The US rejection of the Kyoto Protocol is unfair and puts European business at a disadvantage. With Bush's increasing rejection of international agreements that are essential to protect our environment, Europe should have every right to penalise US goods for the pollution they cause." (Friends of the Earth Europe, 2002).
} 


\subsection{Shielding sectors more vulnerable to global competition}

One way is to bifurcate segments of the economy into two tracks and to shield those segments more vulnerable to global competition. At the international level, we have witnessed horizontal climate negotiations among different countries. Such negotiations have led to the Kyoto Protocol, with binding emissions targets set for industrialized countries. Once the emissions target is agreed on for each industrialized country, the next question is how the country in question translates aggregate commitments into sectorspecific targets. This will involve vertical negotiations between governments and domestic interest groups. Although the ultimate responsibility for fulfilling the Kyoto commitments remains the national government as a Party to the Protocol, governments count on companies' cooperation on emissions control. After all, the companies are entities that emit greenhouse gas emissions. There is no use to defend stringent emissions targets on high moral ground in international horizontal negotiations if governments are unable to work out the burden-sharing agreements with domestic companies in vertical negotiations.

Because energy-intensive industries are major carbon emitters, it should come as no surprise that carbon abatement policies have intended to target these industries. Many economic studies have shown that major energy industries would suffer substantial economic losses. Because potential costs are felt by these concentrated, often wellorganized industries in comparison with widely-spread benefits, they are highly mobilized politically to exert greater influence on political negotiations and policy formulation. As shown by U.S. failure to achieve political success of the Kyoto Protocol, they can even block passage of such policies. All this clearly indicates the proper 
considerations of the distribution of costs among industries are crucial to political feasibility of any proposed policies. This is of particular importance in open economies where fuel-intensive sectors have to compete on international markets with those in countries that have no mandatory emissions commitments. One politically acceptable way of sharing burden cross sectors is to exempt these sectors from the carbon/energy taxes (if adopted) or to give out permits freely to these sectors in the initial allocation of permits (if emissions trading scheme is adopted), either totally or partially. Bovenberg and Goulder (2002) found that exempting about 13 percent of expected emissions from fossil fuel suppliers from the base of a carbon tax or giving out about 13 percent of the permits freely instead of auctioning in an emissions trading scheme in the U.S. suffices to prevent their profits with the emissions constraints from falling in comparison with those without the emissions constraints.

\subsection{Border tax adjustments}

Another is to consider border tax adjustments (BTAs) to offset the international competitiveness effects of domestic carbon abatement measures such as carbon taxes. In the case of involving the use of carbon taxes coupled with some sort of BTAs, exporting countries such as Canada or the EU rebate taxes levied on the products when they are exported, while the importing countries impose the taxes on imported products (U.S. products in this case) that have not been subjected to a similar level of taxes levied on their domestic products. Such adjustments enable a country like Canada or the EU to tax its domestic energy-consuming industries for internal purposes while preserving its competitiveness internationally. It also allows its exports to compete on untaxed markets 
abroad, while ensuring their competitive advantages domestically by taxing imports up to the same level. This kind of BTAs reflects the application to products of the destination principle, which suggests that products should be taxed in the country where they are consumed and not in the country where they are produced unless they are also consumed there.

From a WTO perspective, BTAs, if adopted, should not be used to provide an artificial competitive advantage for domestic products. Thus, border taxes should not be in excess of taxes on "like products" manufactured and sold domestically. Clearly, such adjustments are intended to ensure that internal taxes on products are trade-neutral. BTAs have been used in the U.S. in two important instances of environmental excise taxes: the Superfund Chemical Exercises (Superfund Tax) and the Ozone-Depleting Chemicals (ODC) Tax. With a modest rate of US\$ 4.87 per ton, the Superfund Tax was designed to place the burden of such cleanup on those responsible for generating wastes, but was not intended to influence behaviour through the price system. On the other hand, the ODC Tax aimed to harness market forces to promote the identification of substitutes for the taxed chemicals, and thus was intended to influence behaviour through the price system. This BTA policy turned out to be effective both in raising the price of taxed chemicals and in discouraging their production (Hoerner, 1998).

When considering BTAs for carbon taxes, it is necessary to distinguish between energy products (e.g., coal, oil and gas) from final products (e.g., cars and chemical products). As it would be expected, the application of BTAs to energy products is relatively straightforward. The General Agreement on Tariffs and Trade (GATT)/WTO rules allow the same taxes to be imposed on imported like (energy) products, as well as 
the rebate of indirect taxes on exported domestic products -- as long as there is no discrimination against foreign energy products. However, the situation becomes much more complicated when the products to be imported or exported are not the energy products themselves, but a product whose production or distribution involves the use of taxed energy inputs. Let alone whether such adjustments for imports on the basis of their processes and production methods (PPMs) are in direct conflict with the GATT/WTO principles (see, for example, Stewardson, 1994; Zhang, 1998; Brack et al., 1999), there will be formidable technical difficulties in identifying the appropriate energy/carbon contents embodied in traded products unless exporting countries that do not impose energy/carbon taxes are willing to cooperate in certifying how the products are produced. ${ }^{10}$ In the absence of any information regarding the carbon content of the products from exporting countries, importing countries could, for instance, prescribe the tax rates based on their domestically predominant method of production for the imported products. ${ }^{11}$ In addition to being methodologically challenging, there is the question of whether a tax levied on a product based on the carbon emitted in its production should be regarded as a direct tax or an indirect tax. This would further complicate applying BTAs to imports since GATT rules prescribe that the only BTAs eligible are those levied directly on products, such as excise or value added taxes. Taxes not directly levied on products are not eligible for adjustment,

\footnotetext{
${ }^{10}$ The use of a de minimis floor could substantially reduce the number of products that would be covered in the case of energy/carbon taxes, so that BTAs should be avoided where the tax is trivial percentage of the price. For example, in the case of the above Superfund Tax, BTAs are limited to primary products for which the share of taxable chemicals in production is at least 50 percent, while in the case of the ODC Tax a de minimis rule is applied to non-listed products (Hoerner, 1998). However, the desirability of the use of a de minimis floor to lower substantial administrative burden must be weighted against the environmental effectiveness of energy/carbon taxes.

${ }^{11}$ This practice is by no means without foundation. For example, the U.S. Secretary of the Treasury has adopted the approach in the tax on imported toxic chemicals under the Superfund Tax (Poterba and Rotemberg, 1995; Hoerner, 1998). Nevertheless, such a practice seems very hard to justify in the case of energy/carbon taxes, given the wide range of technologies in use around the world and very different energy resource endowments and consumption patterns among countries.
} 
such as social security charges and payroll taxes. Given the fact that greenhouse gas emissions occurred during the manufacturing process are not really embodied in the product itself when it reaches the border, it is not at all obvious that such a tax would be considered as a direct tax (Cosbey and Cameron, 1999).

Measure of this sort, which would be imposed by Canada, EU and other likeminded countries (to meet their Kyoto targets) on other WTO members like the U.S., may well raise complex questions with respect to the WTO consistency and the conditions under which border taxes can be adjusted to accommodate a loss of international competitiveness.

The issue of compatibility of using trade measures against foreign environmental practices with the GATT has not been brought much attention until the findings of two GATT disputes panels on trade measures unilaterally taken by the U.S. in the U.S.Mexico tuna-dolphin disputes were made public (Hudec, 1996). Both panel reports (GATT, 1991, 1994), which are commonly referred to as Tuna/Dolphin I and Tuna/Dolphin II, found the U.S. restrictions on tuna imports from Mexico, which did not meet the U.S. standards on dolphin-safe fishing practices, in violation of GATT. The panel in Tuna/Dolphin I ruled that all trade restrictions directed against environmental harms have to be territorial. Moreover, such restrictions can not be justified under Article III if they relate to the process of production rather than the product itself. The panel explained that, if governments could regulate imports according to the production process by which they were made, the rules of the GATT's Article III would allow governments to require imports to conform to any type of social regulation currently imposed on the production process of domestic producers. It would allow governments to condition 
market access on compliance with domestic laws governing working conditions. The panel in Tuna/Dolphin II concluded that Article XX does not preclude governments from pursuing environmental concerns outside their national territory, but such extrajurisdictional application of domestic laws would be permitted only if aimed primarily at having a conservation or protection effect. The second panel ruled that the U.S. restrictions were in violation of GATT because they aimed to force other countries to change their own policies in order to comply with the U.S. standards. The two panel rulings indicate that discrimination based on how a product is produced has traditionally had a rough ride in the WTO. ${ }^{12}$ Under WTO rules, an imported product is not allowed to be treated differently to a "like product" (i.e., a product with the same physical characteristics) produced domestically, only on the ground of PPMs employed to produce the product.

Viewed from this angle, border tax adjustments were permitted for environmental taxes or charges on products (ozone-depleting substances) or physically incorporated inputs (e.g., chemicals in plastic products), but not on production processes $\left(\mathrm{CO}_{2}\right.$ emissions) or non-physically incorporated inputs (energy used in production). Following these interpretations, Canada or the EU can adjust taxes at the border to mitigate competitiveness effects of cheaper U.S. products not subject to a similar level of the carbon tax in the U.S.. However, if such adjustments were made on non-physically incorporated inputs, their legality would be doubtful.

\footnotetext{
${ }^{12}$ In dealing with the whole PPMs controversy, a distinction is drawn between product-related PPMs and non-product related PPMs. Product-related PPMs refer to the characteristics of the final product, for example, the environmental impact of a product when it is used or disposed, whereas non-product related PPMs refer to the characteristics of the processes or methods in manufacturing a product or providing a service (OECD, 1997).
} 
However, recent WTO Appellate Body decisions on the Shrimp-Turtle dispute have cast doubt on these interpretations.

To address the decline of sea turtles around the world, in 1989 the U.S. Congress enacted Section 609 of Public Law 101-162 to authorize embargoes on shrimp harvested with commercial fishing technology harmful to sea turtles. The U.S. was challenged in the WTO by India, Malaysia, Pakistan and Thailand in October 1996, after embargoes were levelled against them. The four governments challenged this measure, asserting that the U.S. could not apply its laws to foreign process and production methods. A WTO Dispute Settlement Panel was established in April 1997 to hear the case. The Panel found that the U.S. failed to approach the complainant nations in serious multilateral negotiations before enforcing the U.S. law against those nations. The Panel held that the U.S. shrimp embargo was a class of measures of PPMs type and had a serious threat to the multilateral trading system because it conditioned market access on the conservation policies of foreign countries. Thus, it cannot be justified under GATT Article XX. However, the WTO Appellate Body overruled the Panel's reasoning. The Appellate Body held that a WTO member requires from exporting countries compliance, or adoption of, certain policies prescribed by the importing country does not render the measure inconsistent with the WTO obligation. Although the Appellate Body still found that the U.S. shrimp embargo was not justified under GATT Article XX, the decision was not on ground that the U.S. sea turtle law itself was not inconsistent with GATT. Rather, the ruling was on ground that the application of the law constituted "arbitrary and unjustifiable discrimination" between WTO members (WTO, 1998). The WTO Appellate Body pointed to a 1996 regional agreement reached at the U.S. initiation, namely the 
Inter-American Convention on Protection and Conservation of Sea Turtles, as evidence of the feasibility of such an approach (WTO, 1998; Berger, 1999). Here, the Appellate Body again advanced the standing of multilateral environmental treaties.

What is the significance of this decision and what is its relevance to the Kyoto Protocol? Some analysts (e.g., Ahn, 1999) suggest that the Appellate Body's ruling implies that requiring other WTO members to adopt a comparable regulatory program may not be inconsistent per se with the WTO obligation, if serious efforts were made to reach an international agreement with states whose WTO rights might be affected by an environmental policy measure. This represents a fundamental shift in WTO jurisprudence. The dispute settlement reasoning, if sustained, would permit members to invoke the Article XX exemptions to regulate imports on the basis of non-product related PPMs to accomplish environmental objectives both outside their jurisdiction and in the global commons -- and perhaps to achieve other social objectives (Morici, 2002). ${ }^{13}$ Along this line, Buck and Veheyen (2001) argue that rejecting the Kyoto Protocol, the U.S. resists or even obstructs international cooperation on climate change, and violate its international obligations to cooperate in this field. Thus, the U.S. loses some of its legitimacy to challenge climate change policy measures adopted by more constructive and progressive governments as WTO-incompatible. This does raise an important point in its references to international obligations. Article 18 of the Vienna Convention on the Law of Treaties is relevant in that regard and states as follows:

\footnotetext{
${ }^{13}$ It should be pointed out, though, that there is no universally accepted interpretation of the Appellate Body decision (IPCC, 2001). Other analysts (e.g., Jackson, 2000) argue that such a conclusion that PPMs no longer violate WTO by their very nature is premature legally or has been insufficiently debated and tested in the scientific literature.
} 
"A state is obliged to refrain from acts which would defeat the object and purpose of a treaty when:

(a) it has signed the treaty or has exchanged instruments constituting the treaty subject to ratification, acceptance or approval until it shall have made the intention clear not to become a party to the treaty..."14

This Article requires that a non-ratifying treaty signatory communicates its withdrawal or is held to not violate the treaty's object and purpose. This is why the U.S. withdrew from the International Criminal Court (ICC) - U.S. could has its standing challenged, for example, not to surrender to the ICC any wanted American servicemen. ${ }^{15}$ Similarly, this means that unless the U.S. takes a formal step to withdraw from the UNFCCC, the U.S. could lose some of the protections afforded it under WTO rules in any WTO dispute brought by the EU or other Kyoto Parties. ${ }^{16}$ A WTO Dispute Panel or the Appellate Body could, in keeping with the Vienna Convention and customary international law, deny the U.S. legal standing to challenge, for example, EU measures to enforce Kyoto (Horner, 2002; USCIB, 2002).

Provided that the U.S. takes a formal step to withdraw from the UNFCCC, would trade measures be uphold if challenged by U.S. under WTO? It has been argued that in dealing with transboundary and global environmental problems such as climate change,

\footnotetext{
${ }^{14}$ The Vienna Convention on the Law of Treaties available at $<$ http://www.un.org/law/ilc/texts/treaties.htm $>$.

${ }^{15}$ The ICC was formally launched in Match 2003 in The Hague. Unlike the International Court of Justice, also in The Hague, the ICC is designed to deal with crimes by individuals, not disputes between states. So, for example, whatever the outcome of the dispute within the United Nations Security Council, the ICC will not be able to rule on the legality of invasion of Iraq. The U.S. has campaigned against the court for fear that it will be used to mount politically motivated prosecutions of American government officials (The Economist, 2003).

${ }^{16}$ This is because the U.S. has signed the UNFCCC, even if it has not ratified the Kyoto Protocol to the Framework Convention.
} 
policies and measures adopted through multilateral negotiation processes have better chances to be WTO-consistent and thus avoid unnecessary conflicts and trade disputes. However, the question remains on how the WTO would apply its rules with respect to specific trade-related measures in multilateral environmental agreements (MEAs) when one WTO member country is not a party to such MEAs but is affected by these measures. Could the country affected use WTO rules to overrule the trade measures? This is an issue that need to be clarified under WTO. The EU wants WTO Members to agree that this should not be allowed to happen (European Union, 2001). ${ }^{17}$

\section{Conclusions}

The U.S. and Canada are two important partners of the NAFTA. Canada, together with most industrialized countries, has ratified the Kyoto Protocol and begins implementing domestic policy measures aimed at meeting its legally binding Kyoto emissions target. In the mean time, the U.S. has made clear that it will pursue a separate climate strategy involving only voluntary measures and thus that it will at least initially not be part of the international regime. Given that no other two countries in the world trade as much between themselves as do Canada and the U.S., the U.S. deviation from international obligations makes Canadian industries' competitiveness (trade) concerns become even more rigorous. Against this background, this paper has aimed to address competitiveness

\footnotetext{
${ }^{17}$ In preparing the WTO ministerial conference at Doha, the European Union (2001) "wants to clarify that measures taken to tackle environmental problems under Multilateral Environmental Agreements (MEAs), such as the Kyoto Protocol on Climate Change, are not contrary to WTO rules. For example, problems could arise if a country imposed a trade measure for environmental purposes on another WTO Member that had not signed the MEA. Could the country affected use WTO rules to overrule the trade measures? The EU wants WTO Members to agree that this should not be allowed to happen.".
} 
concerns brought about by the different level playing field where Canadian industries face mandatory emissions constraints but U.S. industry' emissions are uncapped. The following main conclusions have emerged from this analysis.

First, Canadian energy exports to the U.S. are bound to increase under the new U.S. energy security policy. Consequently, this will greatly increase emissions in Canada, and further increase Canada's difficulty in meeting its Kyoto target. One way to deal with increased emissions in Canada as a result of increasing energy exports to the U.S. is to incorporate the abatement cost associated with the production of energy exported in energy pricing. Another way is to increase the amount of cleaner energy exports to the U.S.. Canada has argued that these clean energy exports reduce U.S. and global emissions and thus is entitled to receive credits for the resulting emissions reductions. However, the political and legal uncertainties and technical complexities associated with Canada's proposal have cast the doubt on the likelihood of getting through.

Second, although the ultimate responsibility for fulfilling the Kyoto commitments remains the national government as a Party to the Protocol, governments count on companies' cooperation on emissions control. Located in the territory of Canada, Canadian subsidiaries of U.S. multinationals are obligated to follow the same rules as any other domestic entities and foreign-owned entities in Canada. In the mean time, these subsidiaries are entitled to emissions permits to operate in Canada. No matter which method is used to initially allocate Canada's assigned amount, they should not be treated less favourably than similar domestic entities. Any differential treatments on the basis of ownership in the initial allocation of permits will violate the WTO principle of nondiscrimination. 
Third, the Kyoto Protocol allows the Kyoto Parties like Canada to transfer their Kyoto permits to non-Kyoto Parties like the U.S.. This is very important not only because such a transfer virtually makes U.S. based firms bear mitigation costs but also because it is essential for intra-firm emissions trading within a multinational corporation. This also increases overall demand for Kyoto permits and pushes up the price of permits, thus increasing incentives to invest in clean development projects in developing countries. However, recognising credits from emissions reduction projects in non-Kyoto Parties like the U.S would require an amendment to the Protocol. Canada and other major negotiating Parties have no interest at all in amending the Protocol to recognize those credits and allow them to enter the Kyoto market. Nevertheless it is possible to trade between Kyoto permits and non-Kyoto credits via a clearinghouse system.

Fourth, significant sinks credits allowed in the Marrakech Accords relax the emissions targets substantially. Allowing the unrestricted use of Kyoto flexibility mechanisms further makes much easier for the remaining Annex B Parties to meet their relaxed targets. These two factors would have lowered Canadian compliance costs substantially. In the mean time, the U.S. also incurs economic losses even if it faces no mandatory constraints. Many EU countries, although awarded with less sinks credits in the Marrakech Accords than Canada, even intend to do more than the minimum that would be required under the Kyoto Protocol. The combined effects suggest that additional costs bored by Canada would appear not that high relative to the U.S. and the EU as they appear at fist glance.

Finally, in addition to taking advantage of the opportunities offered by the Kyoto flexibility mechanisms, Canada would further mitigate competitiveness (trade) concerns 
brought about by the different level playing field, by means of shielding those sectors more vulnerable to global competition and invoking trade measures against non-Kyoto Parties. The Appellate Body's ruling on the Shrimp-Turtle dispute implies that requiring other WTO members to adopt a comparable regulatory program may not be inconsistent per se with the WTO obligation, if serious efforts were made to reach an international agreement with states whose WTO rights might be affected by an environmental policy measure. This represents a fundamental shift in WTO jurisprudence. Unless the U.S. takes a formal step to withdraw from the UNFCCC, the U.S. could lose some of the protections afforded it under WTO rules in any WTO dispute brought by Canada, the EU or other Kyoto Parties. A WTO Dispute Panel or the Appellate Body could, in keeping with the Vienna Convention and customary international law, deny the U.S. legal standing to challenge policies and measures that Canada, the EU and other like-minded countries put in place to enforce the Kyoto Protocol.

It should be pointed out that my discussion in this paper focuses primarily on the first commitment period. I argue that the issue of competitiveness in the U.S. and Canada context is a little bit exaggerated. Some may share this view, but still question that there might be long-term problems arising in the second and third commitment periods, provided that the U.S. still remains outside the Kyoto regime. In my view, this is the legitimate concern, but overall competitiveness concerns mean that no country is likely to step out too far in front. Provided that the U.S. would still remain outside the Kyoto regime at that time, it is hard to imagine that Kyoto Parties like Canada would assume future commitments that they regard overly costly and unfair. 


\section{Acknowledgements}

This paper was presented at the Second North American Symposium on Assessing the Environmental Effects of Trade, 25-26 March 2003, Mexico City, Mexico. The author gratefully acknowledges support from the Commission for Environmental Cooperation of North America in the development of this research. The views expressed here are those of the author. The author bears sole responsibility for any errors and omissions that may remain.

\section{References}

Ahn, D. (1999), Environmental Disputes in the GATT/WTO: Before and after the USShrimp Case, Michigan Journal of International Law, Vol. 20, pp. 819-870.

Babiker, M.H., Jacoby, H.D., Reilly, J.M. and D.M. Reiner (2002), The Evolution of a Climate Regime: Kyoto to Marrakech and Beyond, Environmental Science \& Policy, Vol. 5, No. 3, pp. 195-206.

Baumol, W.J. and W.E. Oates (1988), The Theory of Environmental Policy, 2nd Edition. Cambridge University Press, Cambridge.

Berger, J.R. (1999), Unilateral Trade Measures to Conserve the World's Living Resources: An Environmental Breakthrough for the GATT in the WTO Sea Turtle Case, Columbia Journal of Environmental Law, Vol. 24, pp. 355-411.

Bodansky, D. (2002), Linking U.S. and International Climate Change Strategies, Pew Center on Global Climate Change, Arlinton. 
Bovenberg, A.L. and L.H. Goulder (2002), Addressing Industry-Distributional Concerns in U.S. Climate Change Policy, Unpublished manuscript, Department of Economics, Stanford University.

Brack, D., Grubb, M. and C. Windram (1999), International Trade and Climate Change Policies, The Royal Institute of International Affairs and Earthscan, London.

Buck, M. and R. Verheyen (2001), International Trade Law and Climate Change - A Positive Way Forward, Stabsabteilung der Friedrich-Ebert-Stiftung, Bonn. Cosbey, A. and J. Cameron (1999), Trade Implications of the Kyoto Protocol, International Institute for Sustainable Development, Winnipeg, Manitoba, Canada.

Cramton, P. and S. Kerr (2002), Tradeable Carbon Allowance Auctions: How and Why to Auction not Grandfather, Energy Policy, Vol. 30, No. 4, pp. 333-345.

DEFRA (2001), A Summary Guide to the UK Emissions Trading Scheme, United Kingdom Department for Environment, Food, and Rural Affairs, London. DOE (2001), International Energy Outlook, Energy Information Administration, U.S. Department of Energy (DOE), Washington, DC.

ELI (1997), Implementing an Emissions Cap and Allowance Trading System for Greenhouse Gases: Lessons from the Acid Rain Program, Environmental Law Institute (ELI), Washington, DC.

Ellerman, A.D., Schmalensee, R., Joskow, P.L., Montero, J.P. and E.M. Bailey (1997), Emissions Trading under the U.S. Acid Rain Program: Evaluation of Compliance Costs and Allowance Market Performance, Center for Energy and Environmental Policy Research, Massachusetts Institute of Technology. 
European Union (1999), Community Strategy on Climate Change: Council Conclusions, No. 8346/99, Brussels, 18 May.

European Union (2001), Trade and the Environment: Support Sustainable Development,

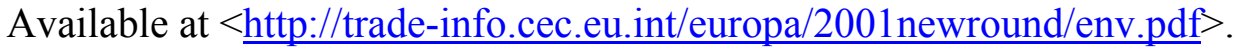

Fauteux, P. (2002), Party/Non-Party Emissions Trading: Compatibility Now, Convergence Later?, Notes Presented at IETA Side Event on Convergence of GHG Regimes and Linking Trading Schemes, Bonn, Germany, 10 June.

Friends of the Earth Europe (2002), EU Should Target US Genetically Modified Food and Energy Intensive Products in Trade Dispute, Press Release on 16 September, available at <http://www.foeeurope.org/press/AW 16_09_02_GMOsynergy.htm>.

GATT (1991), United States - Restrictions on Imports of Tuna, Report of the Panel DS21/R, September 3, General Agreement on Tariffs and Trade (GATT), Geneva.

GATT (1994), United States - Restrictions on Imports of Tuna, Report of the Panel DS29/R, June 16, General Agreement on Tariffs and Trade (GATT), Geneva.

Hausker, K. (1992), The Politics and Economics of Auction Design in the Market for Sulfur Dioxide Pollution, Journal of Policy Analysis and Management, Vol. 11, pp. $553-572$

Hoerner, J.A. (1998), The Role of Border Tax Adjustments in Environmental Taxation: Theory and U.S. Experience, Presented at the International Workshop on Marketbased Instruments and International Trade, Amsterdam, 19-20 March.

Horner, C.C. (2002), Kyoto at the WTO, National Post, 11 October. 
Hudec, R.E. (1996), GATT Legal Restraints on the Use of Trade Measures against Foreign Environmental Practices, in J. Bhagwati and R.E. Hudec (eds.), Fair Trade and Harmonization: Prerequisites for Free Trade?, Volume 2: Legal Analysis, The MIT Press, Cambridge, Massachusetts, pp. 95-174.

IISD (2002), Summary of the Sixteenth Sessions of Subsidiary Bodies to the UN

Framework Convention on Climate Change, 5-14 June, Earth Negotiation Bulletin, Vol. 12, No. 200, International Institute of Sustainable Development (IISD), Winnipeg, Canada.

IPCC (2001), Climate Change 2001: Mitigation, Contribution of Working Group III to the Third Assessment Report, Intergovernmental Panel on Climate Change (IPCC), Cambridge University Press, Cambridge.

Jackson, J.H. (2000), Comments on Shrimp/Turtle and the Production/Process Distinction, European Journal of International Law, Vol. 11, No. 2, pp. 303-307.

Legge, T. (2001), The Unexpected Triumph of Optimism over Experience, CEPS Commentary, Center for European Policy Studies (CEPS), Brussels.

Löschel, A. and Z.X. Zhang (2002), The Economic and Environmental Implications of the US Repudiation of the Kyoto Protocol and the Subsequent Deals in Bonn and Marrakech, Weltwirtschaftliches Archiv - Review of World Economics, Vol. 138, No. 4, pp. 711-746.

Manne, A. and R. Richels (2004), US Rejection of the Kyoto Protocol: The Impact on Compliance Costs and $\mathrm{CO}_{2}$ Emissions, in Z.X. Zhang (guest editor), Special Issue on An Economic Analysis Of Climate Policy: Essays in Honour of Andries Nentjes, Energy Policy, Vol. 32. 
Milliman, S.R. and R. Prince (1989), Firm Incentives to Promote Technological Change in Pollution Control, Journal of Environmental Economics and Management, Vol. 17, pp. 247-265.

Morici, P. (2002), Reconciling Trade and the Environment in the WTO, Economic Strategy Institute, Washington, DC.

Nemry, F. (2001), LULUCF39 v4 - Quantitative Implications of the Decision -/CP.7 on LULUCF, Personal Communication.

OECD (1997), Process and Production Methods (PPMs): Conceptual Framework and Considerations on Use of PPMs-based Trade Measures, OECD/GD(97)137, Paris.

Parry, I.W., Williams III, R.C. and L.H. Goulder (1999), When Can Carbon Abatement Policies Increase Welfare? The Fundamental Role of Distorted Factor Markets, Journal of Environmental Economics and Management, Vol. 37, pp. 52-84.

Poterba, J.M. and J.J. Rotemberg (1995), Environmental Taxes on Intermediate and Final Goods When Both Can Be Imported, International Tax and Public Finance, Vol. 2, pp. 221-228.

Stavins, R.N. (1998), What Can We Learn from the Grand Policy Experiment? Lessons from $\mathrm{SO}_{2}$ Allowance Trading, Journal of Economic Perspective, Vol. 12, pp. 6988.

Stewardson, R. (1994), The Case of Carbon Taxes, in OECD (ed.), Trade and Environment: Process and Production Methods, Paris, pp. 93-108.

The Economist (2003), The International Criminal Court: Soon It Will Be Dispensing Justice, 15 March. 
Tietenberg, T., Grubb, M., Michaelowa, A., Swift, B. and Z.X. Zhang (1999), International Rules for Greenhouse Gas Emissions Trading: Defining the Principles, Modalities, Rules and Guidelines for Verification, Reporting and Accountability, UNCTAD/GDS/GFSB/Misc.6, United Nations, New York and Geneva.

UNFCCC (2001), Review of the Implementation of Commitments and of other Provisions of the Convention. Preparations for the First Session of the Conference of the Parties Serving as the Meeting of the Parties to the Kyoto Protocol (Decision 8/CP.4): Decision 5/CP.6, Implementation of the Buenos Aires Plan of Action, United Nations Framework Convention on Climate Change (UNFCCC), FCCC/CP/2001/L.7, Bonn.

UNFCCC (2002a), Proposal on Cleaner or Less Greenhouse Gas-Emitting Energy: Submission from a Party, FCCC/SBSTA/2002/MISC.3/Add.1, Bonn, 5 June. UNFCCC (2002b), Proposal on Cleaner Or Less Greenhouse Gas-Emitting Energy Report on the UNFCCC Workshop on Cleaner or Less Greenhouse Gas-Emitting Energy: Exchange of Information and Views, Whistler, Canada, 7-8 May, FCCC/SBSTA/2002/INF.8, Bonn, 3 June.

USCIB (2002), WTO Rules and Procedures and Their Implication for the Kyoto Protocol, A Background Paper, United States Council for International Business, Washington, DC, available at $<\underline{\text { http://www.uscib.org/index.asp?documentID=2323 }>}$.

Vaughan, S. (1997), Tradeable Emissions Permits and the WTO, Presented at the European Union Advanced Study Course on Goals and Instruments for the Achievement of Global Warming Mitigation in Europe, Berlin, 20-26 July. 
White House (2002), U.S. Climate Strategy: A New Approach, Policy Briefing Book, Washington, DC, 14 February.

WTO (1998), The Report of the Appellate Body: United States - Import Prohibition of Certain Shrimp and Shrimp Products, WT/DS58/AB/R, World Trade Organization (WTO), Geneva.

Zhang, Z.X. (1997), The Economics of Energy Policy in China: Implications for Global Climate Change, New Horizons in Environmental Economics Series, Edward Elgar, Cheltenham, England and Northampton, USA.

Zhang, Z.X. (1998), Greenhouse Gas Emissions Trading and the World Trading System, Journal of World Trade, Vol. 32, No. 5, pp. 219-239.

Zhang, Z.X. (1999), Should the Rules of Allocating Emissions Permits be Harmonised?, Ecological Economics, Vol. 31, No. 1, pp. 11-18. 